\title{
Changes in the Chemical Properties of Herbal Cow Ghee during Storage
}

\author{
Binod Kumar Bharti ${ }^{*}$, Anamika Das ${ }^{1}$, Sushma $^{2}$, S. N. Thakur ${ }^{1}$, \\ Suvartan Ranvir ${ }^{1}$ and John David ${ }^{1}$ \\ ${ }^{1}$ Warner College of Dairy Technology, ${ }^{2}$ Jacob Institute of Biotechnology and Bio- \\ Engineering, SHUATS, Prayagraj (U.P.), India \\ *Corresponding author
}

\begin{abstract}
A B S T R A C T
Gheeis a traditional dairy product in India. Ghee is generally prepared from cow milk and buffalo milk andit hasgot a typical pleasing and appetizing aroma.In Ayurveda, ghee has been widely used as a medium for delivering different Ayurvedic medicine. Many types of herbal ghee are available in the market. In the present study, Investigation were made to observe the chemical changes that takes place in ghee supplemented with flaxseed oil and brahmi herbs during storage. Flaxseed oil and brahmi herbs are known for their health beneficials aspects. The sample of herbal cow ghee was analyzed for Reichert-Meissl Value, Polenske Value, Iodine Value, Saponification Value, Moisture Percentage, Fat Percentage, Antioxidant Activity (\%DPPH Radical Scavenging Activity), Free Fatty Acid (\% Oleic acid), Peroxide Value (Millimoles/gm of sample) and Thiobarbituric Acid (mg malonaldehyde/kg fat) at ambient temperature. Cow ghee samples of Free Fatty Acid, Peroxide Value and Thiobarbituric Acidwas increased significantly while radical scavenging activity (RSA) of cow ghee samples decreased significantly during storage at ambient temperature.
\end{abstract}

\section{Introduction}

Gheeis a traditional dairy product in India. Ghee is generally prepared from cow milk and buffalo milk andit has got a typical pleasing and appetizing aroma. In Ayurveda, ghee has been widely used as a medium for delivering different Ayurvedic medicine. Many types of herbal ghee are available in the market. During storage condition, ghee undergoes the oxidative degradation (Shende et al., 2014; Gandhi et al., 2013; Pawar et al., 2012) and the level of degradation depends mainly on the storage temperature, oxygen availability and condition of ghee either solid state or liquid state. Oxidative deterioration of ghee degrades by colour, flavour, aroma and nutritive value. Ghee affecting suitability for consumption and reducing the shelf-life of the product (Choe and Min 2006; Gandhi et al., 2013; Pawar et al., 2012). The use of antioxidants to prevent lipids oxidation and also protect oils from the damages caused by oxidized products like free radicals (Yassari and Yasari, 2013). From time immemorial, it is an important part of Indian diet which 
possess many medicinal and therapeutic properties (Heyn, 1993).

Today, flaxseed is cultivated in over 2.6 million ha and the major linseed growing countries are India, United States, China and Ethiopia. India holds $4^{\text {th }}$ ranks with 0.15 million tonnes of total flaxseed production (FAO, 2012). It was first introduced in United States, primarily to produce fiber as a clothing material (Laux, 2011). Flaxseed is also known as Linseed is known for medicinal properties since ancient ages. Flaxseed has potential health benefits for the nutrition three main reason are due to high content of omega- $3 \alpha$ linolenic acid, being rich in dietary soluble and insoluble fibers and due to high content of lignans, it acting as an anti-oxidants and phytoestrogens.

The health benefits of $\omega-3$ fatty acids have been several conditions such as cardio vascular disease, hypertension, atherosclerosis, arthritis, diabetes, cancer, osteoporosis, autoimmune and neurological disorders (Simopoulos, 2000; GogusandSmith, 2010). Flaxseed has also been acts as antiarrhythmic (Ander et al., 2004).

In the traditional system of medicine that was practised in India, Brahmi was one of the unique herbs prescribed for improving the cognitive ability of human beings. Traditionally, Brahmi is used as a brain tonic to enhance the memory growth, learning, and concentration (Mukherjee et al., 1966). Brahmi is to provide relief to patients with anxiety or epileptic disorders (Chopra, 1958). The brahmi plant has also been used as a digestive aid, cardiac tonic and also to improve respiratory function specially in cases of bronchoconstriction (Nadkarni, 1988).

Till date, no studies have been carried out wherein both brahmi herb and flaxseed oil, together have been supplemented in ghee. Also, there is no data available which can illustrate the changes that may take place during storage of such samples at room temperature.

In the present investigation, efforts were made to study the changes in chemical parameters that occurs during storage of cow ghee supplemented with brahmi herb and flaxseed oil at ambient temperature.

\section{Materials and Methods}

The Experimental work was carried out in the research laboratories of Warner College of Dairy Technology, Sam Higginbottom University of Agriculture, Technology and Sciences, Prayagraj (U.P.).

\section{Procurement of raw materials}

Cow and Buffalo milk was collected from local farms of Prayagraj. Ghee was prepared from cream of cow and buffalo milk in Dairy Chemistry laboratory, Warner College of Dairy Technology, SHUATS, Prayagraj. Flaxseed oil was collected from Kamani Oil Industries Pvt. Ltd., Khopoli, Maharashtra, India. Brahmi was procured from Patanjali Pvt.Ltd., Haridwar, India

\section{Preparation of herbal cow ghee samples}

Cow cream was separated from cow milk at $40^{\circ} \mathrm{C}$. Then pasteurization of cream was done at $77^{\circ} \mathrm{C}$ for $5 \mathrm{~min}$, there after cooling was done at of cream at $5-10^{\circ} \mathrm{C}$. further the cream was heated and subjected to clarification at 113$115^{\circ} \mathrm{C} /$ flash. There after the brahmi leaves were added @10\%.The ghee was filtered. At a temp of around 40C, flaxseed oil was added @ $10 \%$. The samples were kept in amber colour PET jar which was kept at room temperature $\left(37 \pm 1^{\circ} \mathrm{C}\right)$. 
Analysis of herbal cow ghee samples for chemical parameters during storage

The cow ghee samples were analyse data intervals of 7 days for Reichert-Meissl Valueas described in Indian standard (IS: 3508-1966), Polenske Valueas described in Indian standard (IS: 3508-1966), Iodine Valueas determined by using Wijs solution as described in SP: 18 (Part XI) - 1981, Saponification Valueas described in SP: 18 (Part XI) - 1981), Moisture Percentageas described in SP: 18 (Part XI) - 1981), Fat Percentage as described in SP: 18 (Part XI) 1981), Antioxidant Activity (\%DPPH Radical Scavenging Activity) as determined by Espin et al., 2000, Free Fatty Acid (\% Oleic acid) as described in Indian standard (IS: 3508-1966), Peroxide Value (Millimoles/gm of sample)as per the procedure described in SP: 18 (Part XI) - 1981 and Thiobarbituric Acid (mg malonaldehyde $/ \mathrm{kg}$ fat) at ambient temperature.

\section{Statistical analysis}

The observation recorded in present investigation were analysed for ANOVA and Critical Difference using WASP software developed by ICAR Research complex at GOA.

\section{Results and Discussion}

In the present study, cow Ghee was incorporated with Brahmi leaves and flaxseed oil and thereafter storage study at room temperature $\left(37 \pm 1^{\circ} \mathrm{C}\right)$ was conducted for 42 days.

The samples of herbal cow ghee was analyzed for chemical parameters at ambient temperature.

The results obtained in the present study related to preparation of herbal cow ghee with incorporation of flaxseed oil and brahmi leaves are being presented below.

Effect of incorporation of flaxseed oil and brahmi leaves on Reichert-Meissl Value of herbal Cow ghee samples during storage at room temp

In the present investigation, Reichert-Meissl Value was recorded 25.32 for $0^{\text {th }}$ day and $7^{\text {th }}$ day, $14^{\text {th }}$ day, $21^{\text {st }}$ day, $28^{\text {th }}$ day, $35^{\text {th }}$ day and $42^{\text {nd }}$ day has the mean value of $25.30,25.30$, $25.29,25.28,25.27$ and 25.26 respectively.

It has been observed that the Reichert-Meissl Value of the cow ghee samples analyzed at different intervals viz. after $7^{\text {th }}$ day, after $14^{\text {th }}$ day, after $21^{\text {st }}$ day, after $28^{\text {th }}$ day, after $35^{\text {th }}$ day and after $42^{\text {nd }}$ day were found to be significantly different $(p<0.05)$.

Effect of incorporation of flaxseed oil and brahmi leaves on Iodine Value of herbal Cow ghee samples during storage at room temp

In the present investigation, at room temperature, the Iodine Value was recorded 69.38 for $42^{\text {nd }}$ day and $35^{\text {th }}$ day, $28^{\text {th }}$ day, $21^{\text {st }}$ day, $14^{\text {th }}$ day, $7^{\text {th }}$ day and $0^{\text {th }}$ day has the mean value of $69.37,69.36,69.34,69.32$, 69.31 and 69.29 respectively.

The result shown that the longer the storage period increase the mean value of herbal cow ghee. Gandhi et al., (2017) observed that the Iodine value for pure cow ghee ranged from 35.53 to 41.24 .

It has been observed that the Iodine Value of the cow ghee samples analyzed at different intervals viz. after $7^{\text {th }}$ day, after $14^{\text {th }}$ day, after $21^{\text {st }}$ day, after $28^{\text {th }}$ day, after $35^{\text {th }}$ day and after $42^{\text {nd }}$ day was found to be significantly different $(\mathrm{p}<0.05)$. 
Fig.1 Graph showing Reichert-Meissl value, iodine value, saponification value,fat percentage and antioxidant activity (\%DPPH Radical scavenging activity) of herbal cow ghee samples supplemented with flaxseed oil and brahmi leaves

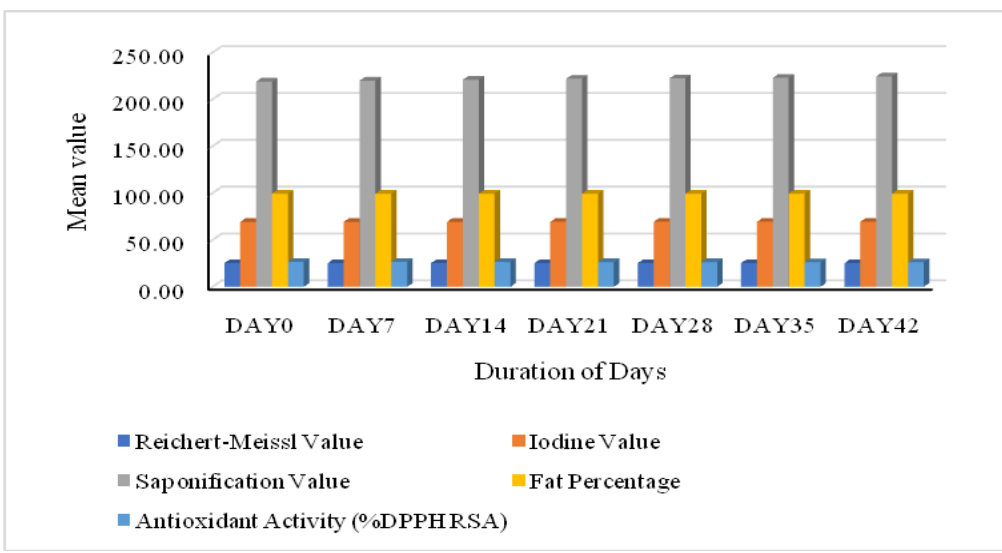

Fig.2 Graph showing Polenske Value, Moisture Percentage, Free Fatty Acid (\% Oleic acid), Peroxide Value (Millimoles/gm of sample) and Thiobarbituric Acid (mg malonaldehyde/kg fat)of herbal cow ghee samples supplemented with flaxseed oil and brahmi leaves

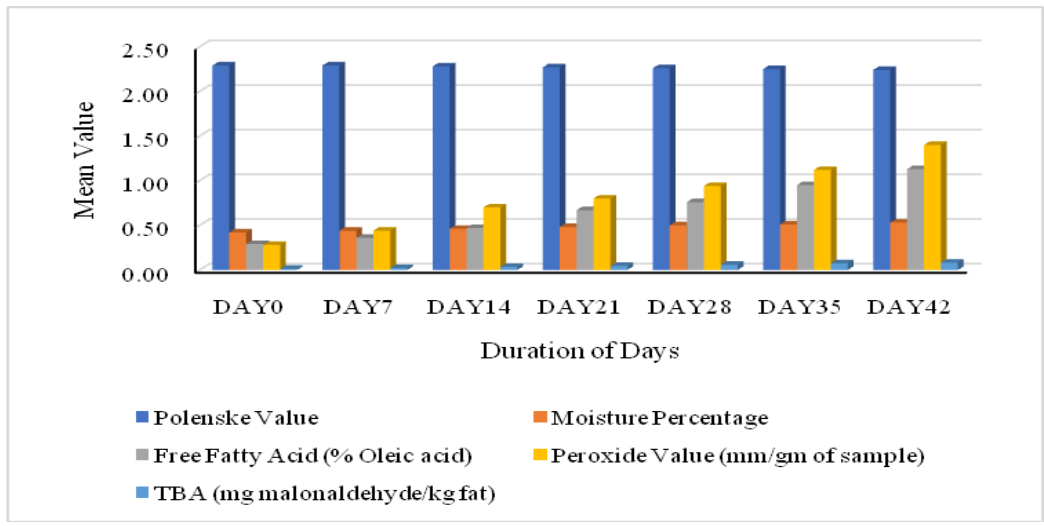

Effect of incorporation of flaxseed oil and brahmi leaves on Saponification Value of herbal Cow ghee samples during storage at room temp

At room temperature, the saponification value was recorded 223.50 for $42^{\text {nd }}$ day and $35^{\text {th }}$ day, $28^{\text {th }}$ day, $21^{\text {st }}$ day, $14^{\text {th }}$ day, $7^{\text {th }}$ day and $0^{\text {th }}$ dayhas the mean value of $223.00,222.50,222.00$, 221.00, 220.00 and 220.00 respectively. The long chain poly unsaturated fatty acids degraded in the presence of oxygen that might be causes decomposition of hydro-peroxide.
From the ANOVA observation, the saponification value of the cow ghee samples stored during day0-day14, day0-day21, day0day28, day0-day35, day0-day42,day7-day21, day7-day28, day7-day35, day7-day42, day14day28, day14-day35, day14-day42, day21day35,day21-day42, day28-day42 and day35day42 was found to be significantly different $(p<0.05)$ and the Saponification Value of the cow ghee sample stored during day0-day 7 , day7-day14, day14-day21, day21-day28, day28-day35 was found to be non-significant $(\mathrm{p}>0.05)$. 
Effect of incorporation of flaxseed oil and brahmi leaves on fat percentage of herbal cow ghee samples during storage at room temp

At room temperature, the Fat percentage was 99.40 for $0^{\text {th }}$ day and $7^{\text {th }}$ day, $14^{\text {th }}$ day, $21^{\text {st }}$ day, $28^{\text {th }}$ day, $35^{\text {th }}$ day and $42^{\text {nd }}$ day has the mean value of 99.39, 99.38, 99.36, 99.35, 99.33 and 99.32 respectively.

It has been observed that the fat percentage of the cow ghee samples analyzed at different intervals viz. after $7^{\text {th }}$ day, after $14^{\text {th }}$ day, after $21^{\text {st }}$ day, after $28^{\text {th }}$ day, after $35^{\text {th }}$ day and after $42^{\text {nd }}$ day were found to be significantly different $(p<0.05)$.

Effect of incorporation of flaxseed oil and brahmi leaves on antioxidant activity (\%DPPH Radical scavenging activity) of herbal Cow ghee samples during storage at room temp

The samples were analysed for Antioxidant activity (\%DPPH Radical scavenging activity) and the observations have been presented below. At room temperature, the Antioxidant activity (\%DPPH Radical scavenging activity) was 26.51 for $0^{\text {th }}$ day and $7^{\text {th }}$ day, $14^{\text {th }}$ day, $21^{\text {st }}$ day, $28^{\text {th }}$ day, $35^{\text {th }}$ day and $42^{\text {nd }}$ day has the mean value of 26.49 , $26.45,26.41, \quad 26.36,26.33$ and 26.28 respectively.

It has been observed that the Antioxidant activity (\%DPPH Radical scavenging activity)of the cow ghee samples analyzed at different intervals viz. after $7^{\text {th }}$ day, after $14^{\text {th }}$ day, after $21^{\text {st }}$ day, after $28^{\text {th }}$ day, after $35^{\text {th }}$ day and after $42^{\text {nd }}$ day were found to be significantly different $(\mathrm{p}<0.05)$.

The observations for Reichert-Meissl Value, Iodine Value, Saponification Value,Fat percentage and Antioxidant activity (\%DPPH
Radical scavenging activity)of herbal cow ghee samples supplemented with flaxseed oil and brahmi leaves during storage at room temperature $\left(37 \pm 1^{\circ} \mathrm{C}\right)$ are presented graphically in fig. no. 1 .

\section{Effect of incorporation of flaxseed oil and brahmi leaves on Polenske Value of herbal Cow ghee samples during storage at room temp}

At room temperature, the Polenske value was recorded 2.29 for $0^{\text {th }}$ day and $7^{\text {th }}$ day, $14^{\text {th }}$ day, $21^{\text {st }}$ day, $28^{\text {th }}$ day, $35^{\text {th }}$ day and $42^{\text {nd }}$ day has the mean value of $2.29,2.28,2.27,2.26,2.25$ and 2.24 respectively.

Chhagan (2013) observed Polenske value in the range of $1.5-1.6$ for cow control ghee samples with added antioxidant (BHA) during storage at $37^{\circ} \mathrm{C}$.

From the ANOVA observation, the Polenske value of the cow ghee samples analyzed at different intervals viz. after $7^{\text {th }}$ day, after $14^{\text {th }}$ day, after $21^{\text {st }}$ day, after $28^{\text {th }}$ day, after $35^{\text {th }}$ day and after $42^{\text {nd }}$ day were found to be significantly different $(\mathrm{p}<0.05)$.

Effect of incorporation of flaxseed oil and brahmi leaves on Moisture percentage of herbal Cow ghee samples during storage at room temp

At room temperature, the Moisture percentage was 0.53 for $42^{\text {nd }}$ day and $35^{\text {th }}$ day, $28^{\text {th }}$ day, $21^{\text {st }}$ day, $14^{\text {th }}$ day, $7^{\text {th }}$ day and $0^{\text {th }}$ day has the mean value of $0.51,0.50,0.48,0.46,0.44$ and 0.42 respectively.

It has been observed that the moisture percentage of the cow ghee samples analyzed at different intervals viz. after $7^{\text {th }}$ day, after $14^{\text {th }}$ day, after $21^{\text {st }}$ day, after $28^{\text {th }}$ day, after $35^{\text {th }}$ day and after $42^{\text {nd }}$ day were found to be significantly different $(\mathrm{p}<0.05)$. 
Effect of incorporation of flaxseed oil and brahmi leaves on Free Fatty Acid (\% oleic acid)of herbal Cow ghee samples during storage at room temp

At room temperature, the Free Fatty Acid (\% oleic acid)was 1.13 for $42^{\text {nd }}$ day and $35^{\text {th }}$ day, $28^{\text {th }}$ day, $21^{\text {st }}$ day, $14^{\text {th }}$ day, $7^{\text {th }}$ day and $0^{\text {th }}$ day has the mean value of $0.83,0.72,0.61,0.53$, 0.44 and 0.29 respectively.

Toyabhai (2012) observed that the Free Fatty Acid (\% oleic acid) for cow milk Arjuna ghee was 0.49. Rajni Kant (2005) reported that the Free Fatty Acid (\% oleic acid) of herbal ghee (arjuna ghee) was found in the ranged from 0.35 to 0.42 .

It has been observed that the Free Fatty Acid (\% oleic acid)of the cow ghee samples analyzed at different intervals viz. after $7^{\text {th }}$ day, after $14^{\text {th }}$ day, after $21^{\text {st }}$ day, after $28^{\text {th }}$ day, after $35^{\text {th }}$ day and after $42^{\text {nd }}$ day were found to be significantly different $(p<0.05)$.

\section{Effect of incorporation of flaxseed oil and brahmi leaves on Peroxide value (Millimoles/gm of sample) of herbal Cow ghee samples during storage at room temp}

The samples were analysed for Peroxide value (Millimoles/gm of sample) at room temperature, the Peroxide value (Millimoles/gm of sample) was 1.40 for $42^{\text {nd }}$ day and $35^{\text {th }}$ day, $28^{\text {th }}$ day, $21^{\text {st }}$ day, $14^{\text {th }}$ day, $7^{\text {th }}$ day and $0^{\text {th }}$ day has the mean value of 1.12 , $0.94,0.80,0.70,0.44$ and 0.28 respectively.

It has been observed that the Peroxide value (Millimoles/gm of sample) of the cow ghee samples analyzed at different intervals viz. after $7^{\text {th }}$ day, after $14^{\text {th }}$ day, after $21^{\text {st }}$ day, after $28^{\text {th }}$ day, after $35^{\text {th }}$ day and after $42^{\text {nd }}$ day were found to be significantly different $(\mathrm{p}<0.05)$.
Effect of incorporation of flaxseed oil and brahmi leaves on Thiobarbituric Acid (TBA) (mg malonaldehyde/kg fat) of herbal Cow ghee samples during storage at room temp

At room temperature, the Thiobarbituric Acid (TBA) (mg malonaldehyde/ $\mathrm{kg}$ fat) was 0.082 for $42^{\text {nd }}$ day and $35^{\text {th }}$ day, $28^{\text {th }}$ day, $21^{\text {st }}$ day, $14^{\text {th }}$ day, $7^{\text {th }}$ day and $0^{\text {th }}$ day has the mean value of $0.073,0.058,0.044,0.034,0.021$ and 0.012 respectively. The result shown that the longer the storage period of herbal cow ghee increase the mean value of Thiobarbituric Acid (TBA) (mg malonaldehyde/kg fat). ElShourbagy (2014) observed that effect of ethanol extract of different concentration of ghee on the Thiobarbituric Acid (TBA)value in the range of $0.013-0.101(\mathrm{mg}$ malonaldehyde/kg fat) during storage period of 21 days.

It has been observed that the Thiobarbituric Acid (TBA) (mg malonaldehyde/kg fat) of the cow ghee samples analyzed at different intervals viz. after $7^{\text {th }}$ day, after $14^{\text {th }}$ day, after $21^{\text {st }}$ day, after $28^{\text {th }}$ day, after $35^{\text {th }}$ day and after $42^{\text {nd }}$ day were found to be significantly different $(\mathrm{p}<0.05)$.

The observations for Polenske Value, Moisture Percentage, Free Fatty Acid (\% Oleic acid), Peroxide Value (Millimoles/gm of sample) and Thiobarbituric Acid (mg malonaldehyde/kg fat) of herbal cow ghee samples supplemented with flaxseed oil and brahmi leaves during storage at room temperature $\left(37 \pm 1^{\circ} \mathrm{C}\right)$ are presented graphically in fig. no. 2 .

In the present study, it may be concluded that herbal cow ghee could be successfully prepared with flaxseed oil and brahmi leaves. Addition of flaxseed oil and brahmi leaves in herbal cow ghee improved the acceptability of the product. The consumption of herbal ghee 
preparation that are responsible for lowering the inflammatory responsible in the human body are being widely consumed. At ambient temp., the Reichert-Meissl Value, Polenske Value, Fat percentage, Antioxidant Activity (\%DPPH Radical Scavenging Activity) was found to slightly decreasewith significance difference $(\mathrm{P}<0.05)$ during storage period of 42 days while the Moisture Percentage, Free Fatty Acid (\% Oleic acid), Peroxide Value (Millimoles/gm of sample) and Thiobarbituric Acid (mg malonaldehyde/kg fat) was found to increasewith significantly $(\mathrm{P}<0.05)$ during storage period of 42 days.

\section{Conflict of interests}

Authors declare no conflict of interests.

\section{References}

Ander B.P., Weber A.R., Rampersad P.P., Gilchrist J.S., Pierce G.N. and Lukas A. (2004). Dietary flaxseed protects against ventricular fibrillation induced by ischemiare perfusion in normal and hypercholesterolemic rabbits. J Nutr 134:3250-3256.

Chhagan, Gosewade Saurabh (2013). A Study on the Physico-Chemical changes occurring in Ghee during Storage thesis submitted Master of Technology in Dairy Chemistry to the National Dairy Research Institute, Karnal (Deemed University).

Choe E. and Min D.B, (2006). Mechanisms and factors for lipid oxidation. Compreh Rev Food Sci. 5:169-186.

Chopra R.N. (1958). Indigenous Drugs of India. 2nd ed. Calcutta, India: U.N. Dhur and Sons; 1958:341.

El-Shourbagy, Gehan A. and El-Zahar, Kahled M. (2014). Oxidative stability of ghee as affected by natural antioxidants extracted from food processing wastes. Annals of
Agricultural Science. 59(2):213-220.

FAO (2012.) FAOSTAT. Food and Agricultural Organization of the United Nations http://faostat3.fao.org/home/index.html

Gandhi K., Arora S., Pawar N. and Kumar A. (2013) Effect of vidarikand (extracts) on oxidative stability of ghee: a comparative study research and reviews. J Dairy Sci Technol. 2(1):111.

Gandhi Kamal, Kumar Anil and Lal Darshan (2017). Iodine value integrated with solvent fractionation technique as a tool for detecting palm olein and sheep body fat adulteration in ghee (clarified milk fat). Indian J. Dairy Sci. 68(4):347-351.

Gogus U. and Smith C. (2010). n-3 Omega fatty acids: a review of current knowledge. Int $\mathrm{J}$ Food Sci Technol 45:417-436.

Heyn B. (1993). The gentle strength of Indian healing. In Ayurvedic Medicine. 112113. Harper-Collins, New Delhi, India

Laux M (2011).

http://www.agmrc.org/commodities__p roducts/grains_oilseeds/flax_profile.cf $\mathrm{m}$

Mukherjee D.G. and Dey C.D. (1966). Clinical trial on Brahmi. I. J Exper Med Sci. 10:5-11.

Nadkarni K.M. (1988). The Indian Materia Medica. Columbia, MO: South Asia Books. Pp. 624-625.

Pawar N., Arora S., Bijoy R.R. and Wadhwa B.K. (2012). The effect of Asparagus racemosus (Shatavari) extract on oxidative stability of ghee, in relation to added natural and synthetic antioxidant. Int J Dairy Technol. 65(2):293-299.

Rajnikant (2005). Development of process for Herbal Ghee, M. Tech. Thesis Submitted to National Dairy Research Institute (Deemed University), Karnal.

Shende S., Patel S., Arora S. and Sharma V. (2014). Oxidative stability of ghee 
incorporated with clove extracts and BHA at elevated temperatures. Int $\mathrm{J}$ Food Prop. 17:1599-1611. doi:10.1080/10942912.2012. 752382

Simopoulos, A.P. (2000). Human requirement for omega-3polyunsaturated fatty acids. Poul Sci 79: 961-970.

Toyabhai, Parmar Pankajkumar (2012). Development of an Improved Process of Production of Herbal Ghee from
Buffalo Milk using Arjuna Extract. Master of Technology in Dairy Technology, Thesis Submitted to National Dairy Research Institute, Karnal (Deemed University).

Yassari S. and Yasari E. (2013). Effect of extract of Thompson orange peels on the stability of canola oil. Int J Agric Crop Sci. 5(4): 450-454.

\section{How to cite this article:}

Binod Kumar Bharti, Anamika Das, Sushma, S. N. Thakur, Suvartan Ranvir and John David 2020. Changes in the Chemical Properties of Herbal Cow Ghee during Storage. Int.J.Curr.Microbiol.App.Sci. 9(11): 3157-3164. doi: https://doi.org/10.20546/ijcmas.2020.911.380 